\title{
Analisis Kegiatan Motorik Kasar di Salah Satu RA Jatinangor
}

Qatrunnada Mufiidah*

Prodi Pendidikan Guru PAUD, Fakultas Tarbiyah dan Keguruan, Universitas Islam Bandung, Indonesia.

*qmufiidah@gmail.com

\begin{abstract}
Gross motor activities are activities that are planned and carried out in every school to improve the gross motor skills of students. Gross motor development activities in one of the RA Jatinangor never use the motion and song method, because they believe that listening to music is haram. This RA is an institution that has the aim of forming early childhood into memorizing the Qur'an so that this institution strongly applies Islamic Shari'a and has also succeeded in producing students who have memorized short letters from chapters 29-30. This research uses a qualitative approach and uses a case study method with data collection techniques in the form of interviews, observations, and documentation studies of the implementation of gross motor development activities at Salah satu RA Jatinangor. The purpose of this study was to obtain data on the methods used in gross motor development. In this study, researchers hope that this RA has a characteristic method in gross motor activities in optimizing the development of gross motor aspects of their students, especially in group A aged 4-5 years. The results of this study are that although the institution does not use motion and song methods in gross motor activities, teachers still use play methods that result in more optimal children's gross motor development and no stage of development in children's gross motor skills is missed.
\end{abstract}

Keywords: Activities, Gross Motor, Early Age.

Abstrak. Kegiatan motorik kasar merupakan kegiatan yang direncanakan dan dilaksanakan pada setiap sekolah untuk meningkatkan kemampuan motorik kasar anak didik. Kegiatan perkembangan motorik kasar di salah satu RA Jatinangor tidak pernah menggunakan metode gerak dan lagu, karena mereka meyakini bahwa hukum mendengarkan musik adalah haram. RA ini merupakan lembaga yang mempunyai tujuan untuk membentuk anak usia dini menjadi penghafal Al-Qur'an sehingga lembaga ini sangat menerapkan syariat-syariat islam dan juga telah berhasil menghasilkan anak didik yang mempunyai hafalan-hafalan surat pendek dari juz 29-30. Penelitian ini menggunakan pendekatan kualitatif serta menggunakan metode studi kasus dengan teknik pengumpulan data berupa wawancara, observasi, dan studi dokumentasi pelaksanaan kegiatan perkembangan motorik kasar di Salah satu RA Jatinangor. Tujuan penelitian ini yaitu untuk mendapatkan data dalam metode yang digunakan dalam perkembangan motorik kasar. Dalam penelitian ini peneliti berharap RA ini mempunyai metode yang ciri khas dalam kegiatan motorik kasar dalam mengoptimalkan perkembangan aspek motorik kasar anak didiknya terutama pada kelompok A usia 4-5 tahun. Hasil dari penelitian ini yaitu walaupun lembaga tersebut tidak menggunakan metode gerak dan lagu dalam kegiatan motorik kasar, namun guru masih menggunakan metode bermain yang menghasilkan perkembangan motorik kasar anak menjadi lebih optimal dan tahap perkembangan pada motorik kasar anak tidak ada yang terlewati.

Kata Kunci: Kegiatan, Motorik Kasar, Usia Dini. 


\section{A. Pendahuluan}

Pendidikan anak usia dini merupakan jenjang pendidikan yang ditempuh oleh anak usia 0-6 tahun sebelum memasuki pendidikan dasar. Dalam pendidikan anak usia dini, akan difokuskan dalam pengembangan aspek nilai norma dan agama, sosial emosional, fisik motorik, kognitif, bahasa dan seni. Berdasarkan Undang-Undang Nomor 20 Tahun 2003 tentang Sisdiknas disebutkan bahwa Pendidikan Anak Usia Dini (PAUD) adalah salah satu upaya untuk membina anak usia lahir sampai enam tahun dengan pemberian stimulus pendidikan untuk membantu dalam meningkatkan aspek pertumbuhan dan perkembangan jasmani dan rohani agar aspek perkembangan anak matang sehingga dapat melanjutkan jenjang pendidikan lebih lanjut. Anak yang berusia 0-6 tahun biasa disebut dengan golden age. Aspek perkembangan yang sangat penting bagi anak usia dini meliputi 6 aspek, yaitu perkembangan dalam nilai dan norma agama, fisik motorik, sosial emosional, kognitif, bahasa serta seni.

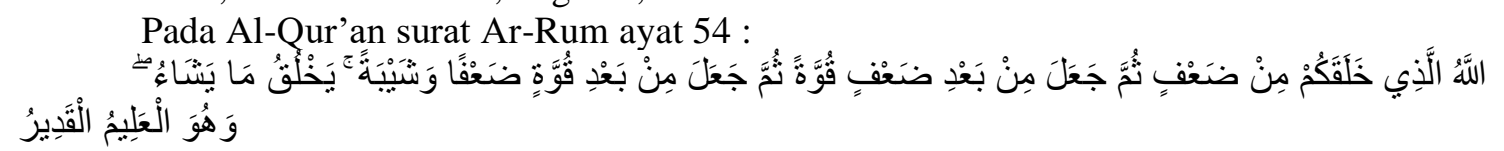

Artinya : Allah, Dialah yang menciptakan kamu dari keadaan lemah, kemudian Dia menjadikan (kamu) sesudah keadaan lemah itu menjadi kuat, kemudian Dia menjadikan (kamu) sesudah kuat itu lemah (kembali) dan beruban. Dia menciptakan apa yang dikehendaki-Nya dan Dialah Yang Maha Mengetahui lagi Maha Kuasa.

An-Nahl ayat 78 :

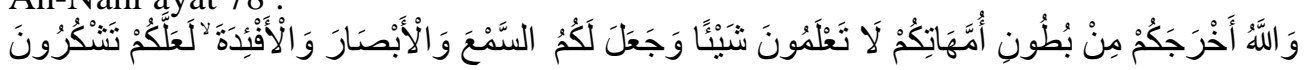

Artinya : Dan Allah mengeluarkan kamu dari perut ibumu dalam keadaan tidak mengetahui sesuatupun, dan Dia memberi kamu pendengaran, penglihatan dan hati, agar kamu bersyukur.

Dalam dua surat di atas, telah dijelaskan bahwa manusia terlahir tanpa dibekali ilmu, belum mengetahui apapun. Tetapi, Allah telah memberikan manusia pendengeran, penglihatan, dan hati. Untuk menerapkan rasa syukur atas ciptaan-Nya, tugas orang tua ketika anak sudah lahir adalah meningkatkan kemampuan indera yang telah Allah beri melalui pendidikan. Pendidikan ini tentu dilakuka pertama kali oleh orang tuanya, melalui pelatihan, pembimbingan dan pengawasan. Misalnya dengan cara membantu anak untuk mencapai aspek perkembangan secara optimal, mengajarkan anak dengan sabar sesuai dengan kemampuan anak, dan tidak lupa untuk mengenalkan ajaran agama dan perilaku baik kepada anak. Ketika anak sudah mencapai usia 3-6 tahun, orang tua dapat dibantu oleh gurunya di sekolah untuk mencapai perkembangan yang lebih optimal.

Salah satu aspek yang perlu dikembangkan adalah fisik motorik, motorik dibagi menjadi dua yaitu motorik kasar dan motorik halus. Penelitian ini akan fokus kepada motorik kasar. Menurut Sujiono (2005: 13) motorik kasar adalah kemampuan otot-otot besar dalam anggota badan disertai koordinasi yang bagus agar menghasilkan gerakan yang optimal (Farida 2016). Sunardi dan Sunaryo (2007: 113-114) menjelaskan bahwa motorik kasar melibatkan otot-otot besar agar anak bisa duduk, berdiri, jalan, berlari. (Pendidikan et al. 2020). Dapat disimpulkan dari dua pendapat para ahli bahwa motorik kasar merupakan kemampuan keterampilan otot-otot besar untuk mencapai perkembangan anak yang optimal.

Tentunya untuk mengembangkan dan mengopitmalkan perkembangan motorik kasar anak, maka dibutuhkan metode. Pada Depdiknas. 2003. 740 disebutkan bahwa secara umum metode merupakan istilah yang sering dijumpai dalam rencana pembelajaran, termasuk dalam kegiatan pembelajaran motorik kasar. Metode adalah cara kerja yang bersistem untuk memudahkan dalam pelaksanaan suatu kegiatan untuk mencapai tujuan yang ditentukan. (Nasional, 1982) Metode merupakan salah satu perencanaan pembelajaran yang penting karena metode juga sebagai penentu keberhasilan dalam mencapai tujuan kegiatan.

Metode yang sering dijumpai pada kegiatan motorik kasar yaitu metode gerak dan lagu. Namun, pada RA ini pihak guru tidak menggunakan musik dengan alasan mereka meyakini bahwa mendengarkan musik adalah haram. Walaupun begitu, RA ini merupakan sekolah yang sudah menghasilkan anak didik dengan memiliki hafalan-hafalan surat pendek dari juz 29-30 yang jarang anak didik lainnya dapatkan. 
Berdasarkan latar belakang yang telah dipaparkan di atas, maka rumusan masalah pada penelitian ini yaitu :

1. Bagaimana metode yang digunakan dalam kegiatan motorik kasar anak usia 4-5 tahun di salah satu RA Jatinangor?

2. Bagaimana media yang digunakan untuk mendukung metode dalam kegiatan motorik kasar di salah satu RA Jatinangor?

Selanjutnya, tujuan dalam penelitian ini diuraikan dalam pokok-pokok sbb.

1. Untuk mengidentifikasi metode yang digunakan dalam kegiatan motorik kasar di salah satu RA Jatinangor,

2. Untuk mengidentifikasi media apa yang digunakan dalam kegiatan motorik kasar di salah satu RA Jatinangor.

\section{B. Metodologi Penelitian}

Dalam penelitian ini menggunakan pendekatan kualitatif dan metode studi kasus. Menurut Prof. Dr. H. Mudjia Rahardjo, M.Si dalam Studi Kasus Dalam Penelitian Kualitatif : Konsep dan Prosedurnya mengatakan bahwa "studi kasus merupakan penelitian ilmiah yang dilakukan secara intensif, dipaparkan secara terperinci dan mendalam, untuk meneliti suatu kejadian, peristiwa, atau program yang dilakukan secara individu, kelompok, maupun suatu lembaga."

Sumber data yang peneliti peroleh yaitu sumber yang diambil dengan melihat secara langsung dari objek yang berkaitan, yaitu informasi yang didapat dari observasi, dan wawancara bersama guru kelas, orang tua, dan anak kelas A yang berhubungan dengan kegiatan perkembangan motorik kasar anak di RA Jatinangor. Menurut Lofland dan Lofland seperti dikutip "Sumber data utama dalam penelitian kualitatif ialah kata-kata, tindakan, dan selebihnya berupa data tambahan seperti dokumen lain yang berkaitan. Berkaitan dengan hal itu pada bagian ini jenis datanya dibagi ke dalam kata-kata tindakan, sumber data tertulis, foto dan statistik. (Moleong, 2011: 157). Sumber data yang digunakan adalah data yang diperoleh melalui informan yang bersangkutan, melalui wawancara dan observasi. Informan adalah orang yang memberikan jawaban atau merespon tentang data yang akan diambil dan bersifat informatif (kualitas dan kedalaman data) mengenai kegiatan perkembangan motorik kasar anak di salah satu RA Jatinangor.

Peneliti melakukan wawancara bersama empat orang tua anak kelas ikhwan, dua orang tua anak kelas akhwat, guru kelas ikhwan, guru kelas akhwat, dan juga bersama anak kelas ikhwan dan kelas akhwat. Observasi dilaksanakan sebanyak lima kali di kelas ikhwan, dan dua kali di kelas akhwat.

\section{Hasil Penelitian dan Pembahasan}

Kegiatan motorik kasar di kelas akhwat dilakukan satu kali dalam seminggu. Kelas ikhwan dilakukan pada hari Rabu sedangkan untuk kelas akhwat dilakukan pada hari Kamis. Tujuan utama yang diharapkan oleh kepala sekolah dan guru kelas adalah agar para peserta didik perkembangan motorik kasarnya tercapai secara optimal.

Kegiatan motorik kasar akan melibatkan guru dan anak didik. Kegiatan motorik kasar yang menarik akan membuat anak didik lebih semangat dalam mengikuti pembelajaran dari awal sampai akhir pembelajaran, dan menciptakan suasana pembelajaran yang menyenangkan.

Adapun metode yang digunakan pada salah satu RA di Jatinangor ini yaitu metode bermain yang kreatif atau creative learning. Walaupun pihak sekolah tidak menggunakan metode gerak dan lagu, namun para guru masih memberikan inovasi untuk kegiatan motorik kasar. Media yang digunakan pada kegiatan motorik kasar selama peneliti melakukan observasi menggunakan bahan media yang aman bagi anak.

Dalam penentuan metode pembelajaran, guru di salah satu RA Jatinangor memilih metode creative learning dengan membuat permainan yang dibentuk secara kreatif dan menyenangkan. Metode yang dapat digunakan dalam meningkatkan kemampuan motorik kasar adalah creative learning. Creative learning adalah pembelajaran yang menonjolkan kreatifitas dalam kegiatannya. Dalam metode ini, guru akan dilatih dalam menuangkan ide untuk membuat suatu konsep, imajinasi, dan gagasan mereka (Florence, 2013:42). Dalam kaitannya dengan 
pengembangan motorik kasar anak, guru dapat menyiapkan kegiatan dengan alat permainan sekreatif mungkin. Sebagai seorang guru, dalam mengaplikasikan permainan yang kreatif merupakan hal yang wajib dalam melakukan kegiatan agar anak merasa senang dalam ikut serta kegiatan. Suatu kegiatan akan berjalan secara efektif apabila di dalamnya sudah ditentukan metode, model, pendekatan maupun teknik. (Iva Rifa, 2012: 26).

Metode creative learning yang dilakukan oleh guru RA di salah satu Jatinangor sudah cukup baik dalam perencanaannya. Guru membentuk permainan yang tidak membosankan bagi anak dan membantu memberikan motivasi kepada anak secara tidak langsung untuk mengikuti kegiatan tersebut agar perkembangan motorik kasar anak meningkat. Metode creative learning menjadi alternatif yang baik pada perencanaan kegiatan motorik kasar di salah satu RA Jatinangor karena guru tidak akan menggunakan metode gerak dan lagu karena para guru meyakini bahwa penggunaan musik adalah haram. Padahal, gerak dan lagu tidak lepas pada kegiatan di Pendidikan Anak Usia Dini. "Kamtini dan Tanjung (2005: 134) mengatakan bahwa "Gerak dan lagu adalah sarana yang menyenangkan bagi anak-anak untuk berolahraga atau senam. Karena dengan gerak dan lagu, anak-anak bias bergerak sambil mendengarkan musik". Ini berarti bahwa ketika anak bergerak sambil mendengarkan lagu maka akan menimbulkan perasaan senang dan semangat, tentu ini bermanfaat untuk kebugaran jasmani dan rohani anak."

Dalam creative learning, guru dapat menggunakan atau memanfaatkan barang yang ada di kelas untuk kegiatan pembelajaran motorik kasar. Seperti, meja belajar. Meja belajar disusun, dan dalam kegiatan meja belajar digunakan agar anak dapat belajar merayap di kolong meja. Di dalam creative learning, anak akan menyesuaikan diri agar ia bisa mendapatkan kesempatan untuk bereksplorasi, berekspresi, dan memberikan gagasan sendiri selama kegiatan berlangsung. Belajar dengan cara kreatif dapat menggunakan semua aspek perkembangan anak, dan membutuhkan keterlibatan penuh dari anak didik.(Sumiyati, 2018)

Mengenai metode gerak dan lagu tidak digunakan oleh guru, namun bukan berarti lagu sepenuhnya tidak digunakan. Hanya saja, sekolah ini tidak menggunakan musik. Para orang tua anak khususnya di kelas ikhwan tidak mempermasalahkan pilihan tersebut, karena para orang tua menganggap perkembangan motorik kasar anaknya tidak mengalami hambatan. Sedangkan, para orang tua di kelas akhwat tidak menuntut sekolah untuk menggunakan musik saat kegiatan karena para orang tua masih dapat memberikan stimulus kepada anaknya di rumah. Sehingga, anak pun tetap mengenali musik dan menari atau bergerak sesuai dengan irama.

Pelaksaan kegiatan motorik kasar merupakan hasil dari perencanaan para guru dalam menentukan kegiatan, tujuan, penilaian, metode, media, dan tempat kegiatan. Pelaksaan kegiatan ini diperoleh datanya melalui wawancara dan observasi sebanyak lima kali pada kelas ikhwan dan dua kali pada kelas akhwat di salah satu RA Jatinangor.

Hasil yang didapat oleh peneliti pada kelas ikhwan dari observasi pertama hingga observasi keempat, kegiatan ini berlangsung tidak kondusif dan tidak efektif. Peneliti melihat para guru ikhwan masih kebingungan dalam mengatur aturan permainan, cara mengkondisikan anak, serta media yang digunakan tidak dikelola dengan baik.

Pada observasi pertama, kondisi anak sangat tidak kondusif dan sulit diatur oleh guru. Guru berpendapat bahwa pemilihan tempat di lapangan SDIT membuat guru kesulitan dala mengatur anak karena luasnya lapangan. Sehingga salah satu guru meminta bantuan kepada peneliti untuk membantu mengatur anak. Kedua, guru masih belum mengerti terhadap aturan permainan yang efektif untuk mencapai tujuan pembelajaran. Tujuan pembelajaran sedikit tidak dipandang oleh guru karena rencana pembelajaran pun tidak ditulis, padahal jika guru membuat RPP dapat menjadi acuan dan dilihat oleh guru saat kegiatan berlangsung.

Observasi kedua dan ketiga, kegiatan motorik kasar dilaksanakan di dalam ruang kelas. Namun kondisi anak juga tidak kondusif, padahal sebelumnya guru sempat tidak bisa mengatur anak di lapangan karena luasnya tempat. Tetapi, walaupun kelas dijadikan tempat berkegiatan, masih terdapat beberapa anak yang tidak fokus, tidak mengikuti aturan guru, tidak mengikuti kegiatan. Memang pada dasarnya anak ada saat nya waktu tidak fokus, namun ini terjadi jika anak bosan. Menurut peneliti, guru memang belum professional dalam mengatur dan memilih kegiatan sehingga anak bosan dan lebih memilih bermain di luar dan di ruang kelas lain. Sehingga beberapa anak juga tidak bisa dinilai sesuai dengan tujuan pembelajaran karena anak 
tidak mengikuti kegiatan tersebut.

Observasi keempat, guru menyediakan media dengan tidak kondusif. Kertas lipat berwarna disimpan dengan tidak menggunakan perekat sehingga kertas pun berterbangan dan tempat lompatan anak tidak beraturan jarak dari kertas ke kertas lainnya. Guru juga tidak mereview kembali nama warna dalam bahasa inggris sebelum anak memulai kegiatan, anak menjadi kebingungan ketika guru menyebutkan nama warna dalam bahasa inggris untuk melompat.

Metode kegiatan diperlukan media sebagai pendukung berjalannya kegiatan dan menjadi motivasi bagi anak untuk mengikuti kegiatan tersebut. Dampak positif menggunakan media dalam pembelajaran disebutkan sebagai berikut (Azhar Arsyad, 2013: 25-26) :

1. Media menjadikan pembelajaran menjadi baku. Media akan langsung memberikan informasi dan tujuan pembelajaran kepada anak.

2. Media menjadi bahan ketertarikan anak untuk mengikuti kegiatan.

3. Dengan adanya media, pembelajaran akan menjadi interaktif.

4. Media dapat memberikan efektivitas dalam penggunaan waktu yang dibutuhkan dalam kegiatan.

5. Kualitas pembelajaran dapat ditingkatkan jika guru memanfaatkan elemen-elemen pembelajaran dengan baik.

6. Media dapat digunakan di mana saja dan kapan saja, apalagi jika media diberikan secara individu.

7. Anak memberikan sikap positif kepada pembelajaran.

Media dalam kegiatan pembelajaran motorik kasar merupakan suatu benda yang mendukung kegiatan berlangsung. Media dapat membuat anak tertarik dalam mengikuti kegiatan, apalagi jika media disajikan dengan sangat menarik oleh guru. Media merupakan perantara bagi pemberi materi untuk menyampaikan infomrasi kepada penerima pesan. Media merupakan segala bentuk dan saluran yang digunakan menyampaikan pesan atau informasi (AECT dalam Arsyad, 2011).

Media mempunyai peran yang sangat penting dalam pembelajaran, media merupakan sarana atau perangkat atau saluran dalam proses komunikasi antara komunikator dan komunikan (Asyar, 2011). Media yaitu alat bantu apa saja yang dapat digunakan dalam menyampaikan pesan untuk mencapai tujuan pembelajaran (Djamarah, 2002). Media dapat menyampaikan informasi melalui suara, gambar, gerakan, dan warna, baik secara alami maupun manipulasi, sehingga membantu guru untuk menciptakan pembelajaran menyenangkan dan tidak membosankan bagi anak.

Media pembelajaran dapat dikatakan sebagai alat bantu guru untuk memberikan stimulus kepada anak didik dalam merangsang pikiran, perasaan, perhatian dan kemampuan atau keterampilan anak sehingga dapat membantu proses belajar untuk mencapai tujuan pembelajaran.

Observasi kelima, permainan menjadi beragam dikarenakan dibantu oleh Ibu Mien. Ibu Mien merupakan guru kelas akhwat. Menurut peneliti, guru ikhwan masih kesulitan mencari permainan yang menarik dan kreatif bagi anak, dan belum dapat menyusun aturan permainan dengan baik, juga belum menemukan cara yang efektif dalam mengatur anak. Karena terdapat perbedaan yang sangat signifikan ketika Ibu Mien membantu para guru ikhwan dalam kegiatan motorik kasar di observasi kelima. Anak cenderung menuruti perintah guru, dan kegiatan berlangsung sangat efektif. Ibu Mien menggunakan media empat meja, anak diperintahkan untuk merayap di kolong meja. Dan juga menggunakan media perosotan, busa hati untuk melompat, dan papan engklek. Anak kelas ikhwan sangat senang mengikuti kegiatan ini karena media yang digunakan membangkitkan semangat anak untuk mengikuti kegiatan dari awal hingga selesai.

Pendapat Arikunto mengenai fungsi guru dalam pembelajaran bahwa :

Pelaksanaan pembelajaran, guru melakukan lima tahapan dalam pelaksanaan pembelajaran yaitu review, overview, presentation, exercise, dan summary. Tahapan review guru harus mendalami kemampuan anak dan mengingat materi sebelumnya. Tahapan overview yaitu guru menyampaikan progam pembelajaran. Tahapan presentation yaitu guru JRPGP is licensed under Creative Commons Attribution- 
menyampaikan materi pembelajaran. Tahapan exercise guru memberikan kesempatan kepada anak didik untuk latihan. Tahapan summary yaitu guru menyimpulkan pembelajaran yang sudah dilakukan.

Sesuai dengan pendapat Arikunto, fungsi guru ikhwan Salah satu RA Jatinangor dalam kegiatan motorik kasar belum maksimal, karena para guru belum bisa melakukan review, overview, dan presentation kepada anak hingga anak mengerti dan dapat diatur saat kegiatan berlangsung. Jika guru dapat melakukan fungsi tersebut, tujuan pembelajaran dipastikan dapat dicapai dan perkembangan anak menjadi meningkat dalam aspek perkembangan motorik kasar. Seperti yang diungkapkan oleh Sumantri (2005: 70) bahwa "motorik kasar anak dapat ditingkatkan sebagaimana berjalannya waktu dengan kemampuan koordinasi antara mata, tangan, dan kaki terus meningkat. Perkembangan motorik kasar dapat dicapai dengan baik apabila anak diberi kesempatan yang besar untuk mencoba kegiatan yang menggunakan seluruh anggota tubuh."

Teori mengenai pelaksanaan kegiatan motorik kasar disebutkan dalam buku "Aplikasi Teori Pembelajaran Motorik di Sekolah" bahwa :

1. Kegiatan motorik bersama guru merupakan sebuah proses bagi anak untuk mendapatkan kemampuan untuk berbagai tindakan. Tindakan ini merupakan gerakan yang bersifat keterampilan. Dengan ungkapan lain, tidak semua anak dapat melakukannya dengan sempurna kecuali anak sudah melakukan latihan dan mengikuti kegiatan motorik kasar di luar sekolah.

2. Kegiatan motorik di sekolah dilaksanakan dengan melalui pengalaman atau praktik langsung oleh anak dengan bimbingan dan pengawasan guru.

3. Dalam mengukur hasil kegiatan motorik terhadap anak di sekolah, para guru tidak bisa menilai kemampuan anak secara singkat. Maka dari itu, guru dapat menyimpulkan dari kegiatan anak di sekolah sehari-hari secara kasat mata dalam kemampuan motorik.

4. Hasil kegiatan motorik secara keseluruhan dapat dilihat dari perubahan anak secara permanen dalam perilaku anak sehari-hari, baik yang ditunjukkan di lingungan sekolah atau luar sekolah.

Jika dilihat dari teori di atas, dan melihat hasil data di lapangan bahwasanya anak sulit dikondisikan dan tidak mengikuti kegiatan motorik kasar, guru tidak akan bisa melihat dan mengukur peningkatan dalam perkembangan motorik kasar anak, karena anak dibiarkan dan tidak dipantau saat anak lepas dari kegiatan dan tidak diberikan dorongan yang lebih maksimal untuk mengikuti kegiatan tersebut guna melihat perkembangan anak.

Observasi pada kelas akhwat menghasilkan data yang bagus, karena guru kelas akhwat membentuk permainan dengan menarik dan guru sangat memperhatikan perkembangan pada setiap anak. Guru kelas akhwat selalu memberikan stimulus kepada anak yang masih belum bisa mencapai indikator kegiatan. Guru akhwat juga selalu mencari pendekatan yang membuat anak didik nyaman agar anak mau mengikuti kegiatan tersebut. Dalam berkegiatan, anak hanya tidak diberikan satu kesempatan dalam mencoba, namun dua sampai tiga kali putaran agar guru dapat menilai dan melihat peningkatan dalam perkembangannya. Sebagaimana yang telah disebutkan kegiatan motorik sebagaimana yang diungkapkan oleh Schmidt (1988), adalah suatu bentuk kegiatan yang berkaitan dengan praktik atau pengalaman yang mengarahkan dalam bentuk perubahan yang relatif permanen dalam kemampuan menanggapi sesuatu (Schmidt, 1988 : 346).

Hasil perkembangan motorik kasar anak di RA ini dari kelas ikhwan dan kelas akhwat menghasilkan perkembangan yang baik. Menurut peneliti, perkembangan anak juga dipengaruhi oleh stimulus yang diberikan oleh orang tua anak. Dari lima orang tua anak kelas ikhwan dan dua orang tua anak di kelas akhwat menghasilkan bahwasanya ada waktu yang diberikan dari orang tua kepada anak untuk berolahraga. Rata-rata waktu olahraga anak bersama orang tua yaitu satu kali dalam seminggu. Maka orang tua memang tidak terlalu mengkhawatirkan perkembangan motorik kasar anaknya, karena mereka mengetahui dan turut andil dalam mengasah aspek perkembangan motorik kasar anak.

\section{Kesimpulan}

Pelaksanaan kegiatan motorik kasar di Salah satu RA Jatinangor berjalan sesuai dengan metode 
bermain berbasis creative learning yang telah dirancang. Dalam memanfaatkan media untuk kegiatan, para guru masih belum memaksimalkan secara efektif. Permainan yang dipilih oleh para guru sudah cukup menarik perhatian anak, namun anak didik harus lebih dikondisikan agar semua mengikuti kegiatan tersebut. Tempat kegiatan dapat dipilah kembali dan memikirkan ruang gerak untuk anak sehingga anak tidak merasa sempit dan bebas untuk bergerak. Para guru sudah mampu dalam memilih permainan sesuai dengan perkembangan motorik kasar anak yang akan dikembangkan, namun akan lebih menarik perhatian anak jika permainan dapat dikembangkan dengan menarik agar anak tidak merasa bosan.

\section{Acknowledge}

1. Bapak Enoh, Drs., M.Ag selaku Dekan Fakultas Tarbiyah dan Keguruan Universitas Islam Bandung.

2. Ibu Dr. Erhamwilda,Dra.,M.Pd selaku Ketua Prodi Pendidikan Guru Pendidikan Anak Usia Dini Universitas Islam Bandung.

3. Dosen pembimbing penulis yaitu Bapak Dr. Asep Dudi Suhardini, S.Ag., M.Pd dan Ibu Nurul Afriant,M.Pd., M.Si.Psi atas bimbingannya selama ini dan telah memberikan waktu, serta ilmu-ilmu yang diberikan kepada penulis untuk kelancaran penyelesaian skripsi.

4. Almarhumah Ibu Yeni Afriyani sebagai kepala sekolah yang telah meninggal pada tanggal 27 Mei 2021. Beliau merupakan salah satu tokoh pendidik di lingkungan Yayasan Mafaza yang memberikan kontribusi besar untuk pendidikan anak usia dini dan memiliki tujuan untuk melahirkan anak didik sebagai penghafal Al-Qur'an serta terkenal atas kebaikan-kebaikannya kepada sesama muslim dan muslimah. Semoga amal ibadah beliau diterima di sisi Allah.

5. Para guru yang telah memberikan waktu, tenaga, serta pengetahuan selama penelitian berlangsung.

6. Orang tua dan anak didik yang telah bersedia meluangkan waktunya untuk melaksanakan wawancara bersama peneliti.

\section{Daftar Pustaka}

[1] Farida, Aida. 2016. "Urgensi Perkembangan Motorik Kasar Pada Perkembangan Anak Usia Dini." Jurnal Raudhah 4(2):10-38.

[2] Pendidikan, Jurusan, Guru Pendidikan, Anak Usia, Fakultas Ilmu Pendidikan, and Universitas Negeri Semarang. 2020. "Kelompok A Melalui Permainan BOCCE Di TK Hj . Istriati Baiturrahman I Semarang."

[3] Sugiyono. (2018). Metode Penelitian Kuantitatif, Kualitatif, dan R\&D. Bandung : Penerbit Alfabeta.

[4] Arsyad Azhar. 2013. Media Pembelajaran. Jakarta : Pt Raja Grafindo Persada

[5] Decaprio, R. (2013). Aplikasi Teori Pembelajaran Motorik Di Sekolah. Jogjakarta : DIVA Press.

[6] Sumiyati, S. (2018) 'Metode Pengembangan Motorik Kasar Anak Usia Dini', AWLADY: Jurnal Pendidikan Anak, 4(1), p. 78. doi: 10.24235/awlady.v4i1.2509.

[7] Sriwahyuniati, F. (2017). Belajar Motorik. Yogyakarta : UNY Press.

[8] Sumiyati, Sumiyati. 2018. "Metode Pengembangan Motorik Kasar Anak Usia Dini." AWLADY: Jurnal Pendidikan Anak 4(1):78. doi: 10.24235/awlady.v4i1.2509.

[9] Nasional, Undang-undang Sistem Pendidikan. 1982. "Introduction and Aim of the Study." Acta Padiatrica 71:6-6. doi: 10.1111/j.1651-2227.1982.tb08455.x. 